\title{
THE FACTORS AFFECTING THE LEVEL OF TRUST BETWEEN BUYER SELLER: AN EXAMPLE FROM HOUSEHOLD APPLIANCES SECTOR
}

\author{
Ebru TÜMER KABADAYI \\ Alev KOÇAK ALAN \\ Ayșe Emsal ERDEBİL \\ * Gebze Institute of Technology, Turkey
}

\begin{abstract}
The purpose of this study is to examine the factors affecting the level of trust and on which way they affect it between channel members in channel system and an example on household appliances sector is given. In this context, trust which is a constructive factor in relationships is affected by manufacturer firm reputation, relationship continuity, conflict and power. As a multi dimensional construct, power is separated into coercive and non-coercive componenets in this study. In order to test the research model, data were collected through a survey in Kocaeli, Istanbul, Bursa, Yalova and Sakarya, Turkey. Regression analysis results confirmed three out of five hypotheses. Statistically significant and positive influences of firm reputation and relationship continuity and negative influence of conflict on trust was found. Nevertheless the influence of coercive and non-coercive power was not found to be significant. The findings indicate that relationship continuity is relatively the most important factor in developing trust between buyer and seller. The results of this study demonstrate some insights to the firms to develop trust with their buyers in order to develop long term, close relationship.
\end{abstract}

Keywords: Distribution Channels, Trust, Relationship Continuity, Conflict, Dependence and Power, Coercive and Non-Coercive Power

\section{INTRODUCTION}

On the contemporary business environment it is impossible for any manufacturer firm to perform all activities and possess all resources by themselves. Due to complications of businesses and stiffness of competition each firm has a strong effect on the success and performance of the others. In this context, manufacturers have begun to develop long term close relationships with their distributors in order to achieve greater efficieny. The necessity of long term close relationships has enhanced the importance of relationship marketing. Relationship marketing consists of all marketing activities in order to establish, develop and maintain long term close relationships between buyers and sellers (Morgan and Hunt, 1994). Long term relationships develop when each party needs to develop and maintain the relationship and it requires economical and individual investments. Due to companies have got a strong effect on each other's sustainable competitive advantage, interorganizational dependency has come into increase (Ganesan, 1994). Since manufacturer firms have begun to develop long term close relationships with few distributors instead of conventional relations, hard competition environment of distribution channel system has emerged. The relationships between buyers and sellers have effected by various factors (Anderson and Weitz, 1989). Few of this factors and also subject of this study are trust, manufacturer firm reputation, relationship continuity, conflict, coercive power and non-coercive power.

\section{TRUST}

Trust is a constitutive factor in interorganizational relationships. The literature on trust suggests that confidence on the part of the trusting party results from the firm belief that the trustworthy party is reliable and has high collectivity which is associated with such characteristics as consistency, competency, honesty, fairness, being responsible, helpful, and benevolent (Morgan and Hunt, 1994, pg.23). Trust demonstrates itself in all stages of a relationships from setting up to developing and maintaining through the long term (Dwyer et al, 1987; Anderson and Weitz, 1989; Moorman et al, 1992; Ganesan, 1994; Morgan and Hunt, 1994). It is a multidimensional construct. It is defined by two dimensions; perceived credibility and benevolence (Ganesan, 1994). The term of credibility stems form the focal party's belief that the exchange partner is reliable and capable of doing what is expected to do. The 
term of benevolence as come to be used to refer to an expectation that the partner "has intentions and motives beneficial to do focal party when new conditions arise" (Sezen and Y1lmaz, 2007, pg.42).

A considerable amount of literature has been mentioned that trust is the one of the most significant factor that makes the continuousness of relationship between organizations, groups and people (Yilmaz, Kabadayi, 2002, pg.101). Channel member always care of its partners welfare and never do anything causing harm to its partner in case of any opportunity (Anderson and Narus, 1990; Ganesan, 1994; Doney and Cannon, 1997). Companies are always come together for sources and therefore there is always a need for commitment. But the relationships with high level of trust provide to each other more benefits and profits that can be obtained in a non-trust relationship (Sezen and Y1lmaz, 2007). Trust reduces conflict and enhances channel member satisfaction (Doney and Cannon, 1997, pg.35). In the early stages of the relations, companies can be more tolerate and understandable in case of any problems and conflicts in order to obtain long term benefits (Anderson and Weitz, 1989). Trust is a reciprocal construct, it develops and builds over time in the relationships after partners experience many satisfied business transactions. Partners in a relationship understand, perceive each other better and predict the future behaviors (Doney and Cannon, 1997). When trust exists, retailers and vendors believe that long term special investments can be made with scant risk because whole sides will refrain from using their power to renege on contracts or use a shift in terms to obtain profits in their favor. Furthermore, trusting relationships are supposably to have made a deduction of transaction costs because incomplete contracts are convenient for running the exchange relationships (Ganesan, 1994, pg.4). Trust is a key factor for maintaining the relations in the long term. Once trust is developed once in a relationship partners will spend more effort, time and source for it (Morgan and Hunt, 1994).

\section{RELATIONSHIP CONTINUITY}

Relationship continuity can be defined as the belief of a company about the relationship sustainability and future continuity of it with the other partner (Anderson and Weitz, 1989). In other words it is an expectation that the relationship will continue in the future. When a firm anticipates the relationship will continue into the future, it is more willing to engage in processes and make investments that will improve the relationship into the long run. Without a confidence in the future of the relationship firms embark on a short time horizon, and reject to engage in activities that do not pay of quickly and with certainty (Jap and Anderson, 2003, pg.1687). An existing relationship will continue when the partners of the relationship provide important benefits and values to each other. Unless they provide value and benefit, they seek alternative partners and so the contingency of ending the relationship will be high (Morgan and Hunt, 1994). Continuity of a relationship is a function of the trust between parties, imbalance of power, communication between parties, stakes in the relationship, manufacturer's reputation for "fair play", age of the play (Anderson and Weitz, 1989, pg. 312). The relationship continuity is important because it increases the investments, cooperation, solidarity, communication, relationship quality and performance which decreases the conflicts in the relationships (Anderson and Weitz, 1989)

In this context the first hypothesis,

$\mathrm{H} 1=$ There is a positive relationship between trust and relationship continuity.

\section{REPUTATION}

Reputation is the belief that a company is honest and concerned about its customers (Doney and Cannon, 1997, pg.325). It is a critical factor that can not be change or delete easily. Especially when there isn't enough information about firms or it is not possible to obtain this information reputation provides an important signal or strong clue to the other firms (Zeithaml, 1998). When partners operate in different geographic locations and/or cultures reputation is always a leading key factor. Having a good reputation for a firm is the most important factor in comparison with the possible other factors in order to be known as a highly trustable firm (Kim et al, 2008). A firm that is highly responsible, satisfies the expectations, keeps its promises, and provides value and benefit for its partner will have a good reputation in channel system as reliable. This reputation will create an opportunity for that firm to be chosen by the potential business partners. There is a positive relationship between firm reputation and trust. A highly trusted firm has good reputation (Anderson and Weitz, 1992; Ganesan, 1994). A firm which has got unfortunate past experiences, has not consider welfare of its partner, taken care of its profits instead of partnership's and frequently ended relationships will cause a bad reputation for the future and won't be chosen as a partner by the others. Firm reputation serves as a schema developed from past experiences with retailer's to form a basis for the consumer's expectations of future experi- 
ences with the store, eventually creating a halo effect. The halo effect created by a good reputation lets customers evaluate the retailer more favorable, even when performance is not satisfactory (Kim et al, 2007, pg.326). Reputation develops through time and it provides sustainable competitive advantage. Reputation can not be duplicated by the others. Reputation attributes the perceptions and turn backs of the others about the company (Williams et al, 2005). A firm with high level of reputation will be a better strategic business partner in comparison with others in the channel system (Dollinger et al, 1997). In this context accordingly the second hypothesis is,

$\mathrm{H} 2=$ There is a positive relationships between Trust and Reputation.

\section{CONFLICT}

Developing a long term relationship can be of considerable benefit but it is not without hardships and unexpected costs (Bradford, 1999, pg.9). Conflict is inevitable. It is pervasive and stem from the natural interdependency inherent in interfirm Exchange relationships (Schul and Babakus, 1988, pg.381). Organizations strive toward maximizing their autonomy thus; mutual interdependencies will tend to create conflicts of interests (Stern and Reve, 1979, pg.409). Conflict in its most general sense can be thought of as overt behavior "arising out of a process in which one unit seeks the advancement of its own interests in its relationship with the others". However, conflict is such an elastic concept that has also been referred to in the marketing literature on channels as (1) A feeling of stress, tension, or hostility of one channel member toward another and (2) The antecedents conditions of conflicting behavior (Lusch, 1976, pg.383). In any social system, an atmosphere of frustration prevails when one of several dependent components perceive another as preventive attainment of its goals or its effective performance (Rosenberg and Stern, 1971, pg.437). Conflict must be effectively managed for an organization to achieve its goals (Pinkely and Northcraft, 1994, pg.193). The hostility and bitterness resulting from disagreements not being resolved amicably can lead to such undesirable consequences as relationship dissolution. When disputes are resolved amicably, such disagreements can be referred to as "functional conflict". Functional conflict may increase the productivity in relationship marketing and be viewed as "just another part of doing business" (Morgan and Hunt, 1994, pg.26). There is a negative relationship between trust and conflict. Trust may increase the functionality of conflict in relationships because in trust-based relationships partners can tolerate tensions and frustrations and avoid engaging in conflicting behaviors (Morgan and Hunt, 1994). Therefore,

$\mathrm{H} 3=$ There is a negative relationship between Trust and Conflict.

\section{DEPENDENCE AND POWER}

Dependence of a manufacturer on a distributor refers to a distributor's need to maintain the channel relationship to achieve desired goals (Ganesan, 1994, pg.4). In general, as soon as the channel members resume mutual interest, they are in struggle for prolongation their relationship (Yilmaz, Kabadayi and Sezen, 2002, pg 182). Dependence rof a distributor on a manufacturer is increased when (1) outcomes obtained by the distributor from the manufacturer are important and highly valued and the magnitude of the exchange is high, (2) outcomes obtained by the manufacturer exceed outcomes available to the distributor from the best alternative manufacturer, and (3) distributor has few alternative sources or potential sources of exchange (Ganesan, 1994, pg.4). Overall interdependence is the sum of both firm's dependence, however interdependence dissymmetry is the difference between the firm dependence on its partner and the partner's dependence on the firm. Symmetric interdependence exists when the firm and its partner are equally dependent on each other (Kumar et al, 1995, pg.349). Power is a function of dependence. The power of a manufacturer over a distributor is related to the dependence of the distributor on the manufacturer (El-ansary and Stern, 1972, pg.47). Power has been described persistently in the marketing channels literature as the ability of one channel member to influence decision variables of another channel member, a potential for influence on another firm's beliefs and behavior (Frazier, 1983, pg.158). This potential for influence has been viewed as a function of: (1) Authority, which represents a firm's prescribed right to influence or specify certain behaviors (2) Dependency, which views a firm's power in a dynamic relationship as a function of the other firm's dependence on the relationship for the achievement of desired goals (Schul and Babakus, 1988, pg.383).

\section{COERCIVE AND NON-COERCIVE POWER}

The power of any reached channel member is likely a function of the resources of power available to them at any given time (El-ansary and Stern, 1972, pg.48). The sources or bases of power can be clas- 
sified as reward, coercive, expert, referent, and legitimate (French and Raven, 1959). The coercive source can be differentiated from the others because it is alone interested potential punishments and therefore the individual stintingly yields power to another. The other four sources are non-coercive because the individual appealingly yields power to another (Lusch, 1976, pg.383). Therefore, Hunt and Nevin have classified power generally into coercive and non-coercive power (Hunt and Nevin, 1974). Coercive source of power is ability of punish and non coercive source of power is ability to provide high quality assistance (Lusch, 1976, pg.383). Influence strategies are the means of communication used by a firm's power. Influence strategies have been classified into coercive and noncoercive. In coercive influence strategies, the source firm puts direct pressure on the target firm to execute a specific behavior by stressing the reverse outcomes of non-compliance. Non-coercive influence strategies primarily focus on the beliefs and attitudes of the target firm about general business issues and involve little, if any, direct force from the source firm (Kim, 2000, pg.389). Firms are less satisfied with partners who use coercive sources of power and more satisfied with those who use no coercive power (Frazier and Rody, 1991). In this context,

$\mathrm{H} 4=$ There is a negative relationship between Trust and Coercive power.

$\mathrm{H} 5=$ There is a positive relationship between Trust and non coercive power.

Figure 1. Research Model

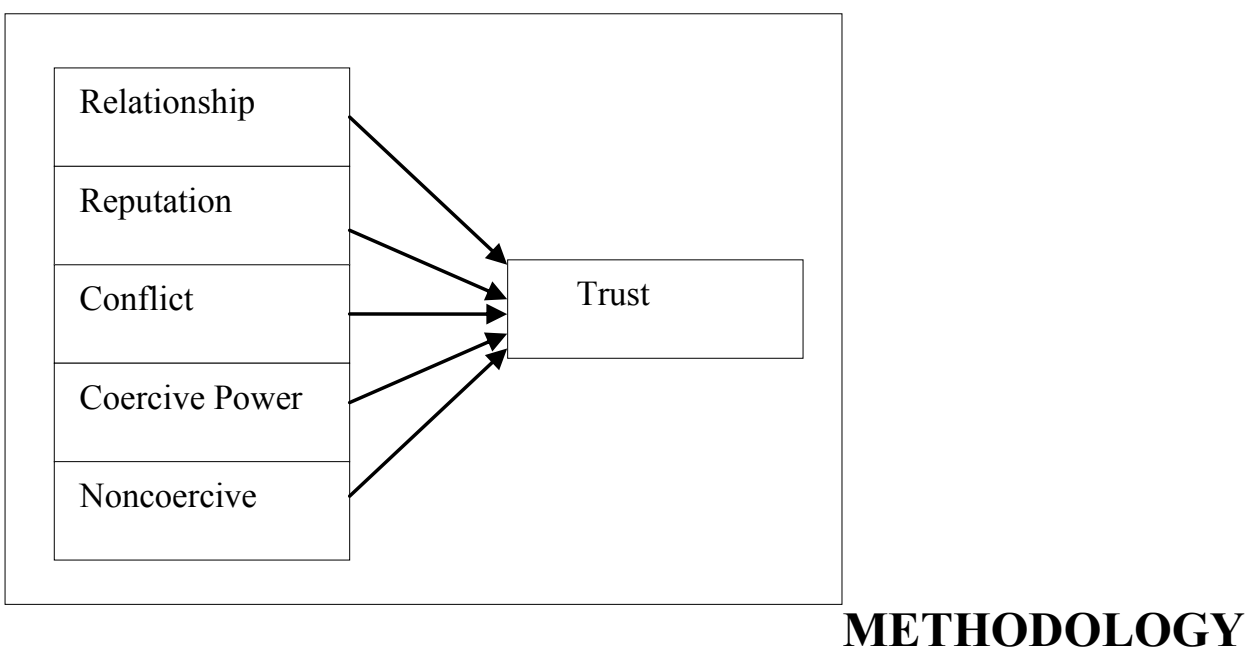

\section{Sample}

To test the research model, data gathered through a survey in Istanbul, Izmit, Bursa, Sakarya, and Yalova, Turkey.

Convenience sampling was used to select the sampling frame. A total of 300 questionnaires were hand delivered and 196 questionnaires were returned. The characteristics of the sample are presented in appendix 1.

\section{MEASUREMENT}

Trust was measured based on five items scale presented by Kabadayı (2002). To measure relationship continuity three items scale presented by Noordewier, John and Nevin (1990). Reputation scale was measured based on three-item scale of five-item scale presented by Kabaday1 (2002). Conflict scale was measured based on three-item scale presented by Leonidas and Talias (2007). Coercive power scale was measured based on three-item scale presented by Leonidas and Talias (2007) and non coercive power scale was measured three items scale of five-item scale presented by Leonidas and Talias (2007). 
Table 1. Factor Loadings of the Scale Items and Cronbach's Alpha Coefficients

\begin{tabular}{|c|c|c|c|c|c|c|c|}
\hline & Cronbach & Com & nent & & & & \\
\hline & & 1 & 2 & 3 & 4 & 5 & 6 \\
\hline Trust & .91 & & & & & & \\
\hline Our manufacturer is honest and true. & & .830 & & & & & \\
\hline $\begin{array}{l}\text { We believe that our manufacturer always } \\
\text { behave fairly. }\end{array}$ & & .815 & & & & & \\
\hline $\begin{array}{l}\text { We have a great confidence that our } \\
\text { manufacturer do its business best }\end{array}$ & & .821 & & & & & \\
\hline Our manufacturer is always loyal to us & & .841 & & & & & \\
\hline $\begin{array}{l}\text { Our manufacturer's statements are always } \\
\text { reliable. }\end{array}$ & & .850 & & & & & \\
\hline Relationship Continuity & .84 & & & & & & \\
\hline $\begin{array}{l}\text { We hope that our relationship will continue for } \\
\text { long years }\end{array}$ & & & & .757 & & & \\
\hline $\begin{array}{l}\text { We desire our relationship with this manufac- } \\
\text { turer always keep in alive }\end{array}$ & & & & 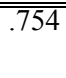 & & & \\
\hline We believe our manufacturer always prefer us & & & & .644 & & & \\
\hline Reputation & .79 & & & & & & \\
\hline $\begin{array}{l}\text { Our manufacturer is known as an honest firm } \\
\text { among the distributors }\end{array}$ & & & & & & .570 & \\
\hline $\begin{array}{l}\text { Many distributors describe this manufacturer } \\
\text { develops appropriate and understandable solu- } \\
\text { tions its problems }\end{array}$ & & & & & & .704 & \\
\hline $\begin{array}{l}\text { Many of the distributors believe this manufac- } \\
\text { turer is fair and honest. }\end{array}$ & & & & & & .679 & \\
\hline Conflict & .78 & & & & & & \\
\hline $\begin{array}{l}\text { There is always a frustrated relationship with } \\
\text { our manufacturer }\end{array}$ & & & & & .806 & & \\
\hline $\begin{array}{l}\text { There are important disagreements occur in our } \\
\text { business with this manufacturer }\end{array}$ & & & & & .836 & & \\
\hline $\begin{array}{l}\text { Our manufacturer is frequently obstructed } \\
\text { working with us }\end{array}$ & & & & & .810 & & \\
\hline Coercive Power & .84 & & & & & & \\
\hline $\begin{array}{l}\text { Failing to comply with their requests will result } \\
\text { in financial and other penalties against our com- } \\
\text { pany }\end{array}$ & & & .654 & & & & \\
\hline $\begin{array}{l}\text { Threatening to withdraw from what they origi- } \\
\text { nally promised, if we don't comply with their } \\
\text { requests }\end{array}$ & & & .825 & & & & \\
\hline $\begin{array}{l}\text { Threatening to take legal action, if we don't } \\
\text { comply with their requests }\end{array}$ & & & .845 & & & & \\
\hline $\begin{array}{l}\text { Withholding important support from our firm, } \\
\text { in requesting compliance with their demands }\end{array}$ & & & .799 & & & & \\
\hline $\begin{array}{l}\text { Threatening to deal with another supplier, in } \\
\text { order to make us submit to their demands. }\end{array}$ & & & .707 & & & & \\
\hline Non-Coercive Power & .67 & & & & & & \\
\hline $\begin{array}{l}\text { Having the upper hand in the relationship, due } \\
\text { to power granted to them by the contract }\end{array}$ & & & & & & & .763 \\
\hline $\begin{array}{l}\text { Demanding our compliance because of knowing } \\
\text { we appreciate and admire them }\end{array}$ & & & & & & & .707 \\
\hline $\begin{array}{l}\text { Withholding critical information concerning the } \\
\text { relationship, to better control our company }\end{array}$ & & & & & & & .725 \\
\hline
\end{tabular}




\section{VALIDITY and RELIABILITY OF MEASURE}

In order to evaluate the construct validity the principal components analysis was conducted using varimax rotation. The results in table 1 show that each scale items were loaded to relevant factors with strong factor loadings addressing the construct validity of the measure. Cronbach's alpha coefficients were evaluated to ensure the reliability of scales. The results presented in table 1 confirmed the reliability of the scales with alpha coefficients ranging from 0,67 to 0 , and 91 .

\section{Descriptive Statistics and Pearson Correlation Analysis}

The means, standard deviation of the variables and coefficients regarding to Pearson's correlation among these variables are shown in Table 2 .

Table 2. Means, Standard Deviations, and Pearson Correlation Coefficients

\begin{tabular}{|l|l|l|c|c|c|c|c|c|}
\hline & Mean & Std. & & & & & & \\
\hline & & Deviation & 1 & 2 & 3 & 4 & 5 & 6 \\
\hline Trust & 4.5327 & .63274 & 1 & & & & & \\
\hline Reputation & 4.2823 & .64468 & $.558^{* *}$ & 1 & & & & \\
\hline $\begin{array}{l}\text { Relationship } \\
\text { Continuity }\end{array}$ & 4.2925 & .72050 & $.576^{* *}$ & $.652^{* *}$ & 1 & & & \\
\hline Conflict & 1.8163 & .92095 & $-.254^{* *}$ & $-.176^{*}$ & $-.183^{*}$ & 1 & & \\
\hline $\begin{array}{l}\text { Coercive } \\
\text { Power }\end{array}$ & 3.0071 & 1.00059 & -.094 & -.117 & $-.155^{*}$ & $\begin{array}{c}.195^{*} \\
*\end{array}$ & 1 & \\
\hline $\begin{array}{l}\text { Non-Coercive } \\
\text { Power }\end{array}$ & 3.5391 & .86341 & -.055 & .135 & .124 & .093 & $.418^{* *}$ & 1 \\
\hline
\end{tabular}

$* *$ Correlation is Significant at the 0.01 Level $*$ Correlation is Significant at the 0.05 Level

\section{RESULTS}

To test the research model a linear multiple regression analysis was performed using SPSS 13, 0 with trust as the dependent variable and reputation, relationship continuity, conflict, coercive power and non-coercive power as independent variables. Results summarized in table 3 show that the model was significant at $\mathrm{p}<.001$ and adjusted $\mathrm{R}$ square $=0.417$ meaning that constructs included in the model explained $43 \%$ of the variation in trust.

Table 3 also presents the standardized beta coefficients indicating the relative effects of reputation, relationship continuity, conflict, coercive power and non-coercive power. This results show support for three of five hypotheses. H1, hypothesis proposing a positive effect of the relationship continuity should increase the level of trust, confirm with 0.378 beta coefficient at $p<0.01$. Positive effect of the reputation on trust is also significant at $p<0,01$ and with 0.324 beta coefficient supporting the $\mathrm{H} 2$. On the other hand, $\mathrm{H} 3$ hypothesis proposing a negative effect of the conflict should decrease the level of trust is confirmed with at $p<0.05$ with -0.131 beta coefficient. It is event from the results that coercive power that should be negatively effective on trust was rejected. H5, Hypothesis proposing that noncoercive power should be as effective associated with trust is also rejected.

Table 3. Regression Analysis Results

\begin{tabular}{|c|c|c|c|}
\hline & Standardized Beta Coefficients & $\mathrm{T}$ & Sig. \\
\hline (Constant) & & 7.220 & $.000^{* *}$ \\
\hline Relationship Continuity & .378 & 5.172 & $.000 * *$ \\
\hline Reputation & .324 & 4.461 & $.000^{* *}$ \\
\hline Conflict & -.131 & -.2307 & $.011 *$ \\
\hline Coercive power & .101 & 1.624 & $.005^{* *}$ \\
\hline Non-Coercive Power & -.176 & -2.835 & $.002 * *$ \\
\hline R Square & \multicolumn{2}{|l|}{.432} & \\
\hline Adjusted R Square & \multicolumn{2}{|l|}{.417} & \\
\hline $\mathrm{F}$ & \multicolumn{2}{|c|}{28.891} & 000 \\
\hline
\end{tabular}




\section{DISCUSSION}

The purpose of the current study was to determine the effects of relationship continuity, reputation, conflict, coercive power and non-coercive power on trust and results provide some useful information. Considering the five selected independent variables together, relationship continuity was found to be effective on building trust. One of the more significant findings to emerge from this study is that, for household appliances distributor's relationship continuity is a significant indicator of trust. It was also shown that reputation has got a significant effect on trust too. On the other hand, results indicate that conflict has significantly negative effect on trust.

The findings of this study have a number of important implications for future practice for managerial, in order to enhance the level of trust on distributors, manufacturers should enhance the positive expectation that the relationship will continue in the future. They should also create a good reputation about being fair and honest business partner, take care of partners' welfare and avoid taken actions which might be detrimental to their partners's interests even though such actions may be beneficial to themselves. They should also refrain themselves from conflict and be more tolerant in order to turn short term mistakes into long term benefits and profits.

In conclusion, relationship continuity and reputation play an essential role with less conflict in developing long term close relationships increasing the level of trust.

\section{APPENDIX}

Appendix 1. sample characteristics

\begin{tabular}{|l|c|l|c|}
\hline & Percent & & Percent \\
\hline GENDER & & MARITAL STATUS & \\
\hline Male & 81,6 & Single & 25,0 \\
\hline Female & 18,4 & Married & 75,0 \\
\hline AGE & & EDUCATION & \\
\hline Less than 18 & - & Primary School & 4,6 \\
\hline From 18 to25 & 12,2 & Elementary School & 8,7 \\
\hline From 26 to50 & 76,1 & High School & 52,6 \\
\hline More than 50 & 11,7 & University & 33,2 \\
\hline & & Master/PHD & 1,0 \\
\hline
\end{tabular}




\section{REFERENCES}

ANDERSON, E. and WEITZ, B.; (1989), "Determinants of Continuity in Conventional Industrial Channel Dyads"; Marketing Science, Fall, 8, 4

ANDERSON, N.J. and NARUS, J.A.; (1990), “A Model of Distributor Firm and Manufacturer Firm Working Partnerships"; Journal of Marketing, 54(Jan), Pg.42-58

BRADFORD, K, (1999); “Conflict Management in Buyer-seller Relationships”; University of Florida DWYER, F.R. and OH, S.; (1987), "Output Sector Munificence Effects on the Internal Political Economy of Marketing Channels"; Journal of Marketing Research, 24, 4, Nov, Pg.347

DONEY, P.M. and CANNON, J.P.; (1997), “An Examination of Nature of Trust in Buyer-Seller Relationships"; 61(2), Pg.35-51

FRAZIER, G.L. (1983), “On the Measurement of Interfirm Power in Channels of Distribution”; Journal of Marketing Research, (May), 20, 000002, Pg.158

FRAZIER, G.L. and RODY, R.C., (1991); “The Use of Influence Strategies in Interfirm Relationships in Industrial Product Channels"; Journal of Marketing, 55(January), Pg.52-69

FRENCH, J.R.P. and RAVEN, B; (1959), "The Bases of Social Power; In Studies in Social Power", Dorwin, Pg.127-140

DWYER, F.R.; SCHURR, P.H. and OH, S.; (1987), “Developing Buyer Seller Relationships”; Journal of Marketing, 51(2), Pg. 1-27

DOLLINGER, M.J.; GOLDEN, P.A. and SAXTON, T.; (1997), "The Effect of Reputation on the Decision to Joint Venture"; Strategic Management Journal, 18(2),

EL-ANSARY, A.I. and STERN, L.W.; (1972); "Power Measurement in the Distribution Channel”; Journal of Marketing Research, (Feb), 9, 000001, Pg.47

GANESAN, S.; (1994), "Determinants of Long Term Orientation in Buyer Seller Relationships"; Journal of Marketing, Vol.58, April, Pg.1-18

HUNT, S.D and NEVIN, J.R.; (1974), "Power in a Channel of Distribution: Sources and Consequences"; Journal of Marketing Research, 11, 000002, may, Pg.186

JAP, S.N. and ANDERSON, E.; (2003); "Safeguarding Interorganizational Performance and Continuity under Ex Post Opportunism"; Management Science, 49, 12, Dec, Pg. 1684

KABADAYI, E.T.; (2002), “Dağıtım Kanallarında İşbirliğini Etkileyen Etmenler: Otomobil Bayileri Üzerine Bir Uygulama”; Doktora Tezi, Gebze Yüksek Teknoloji Enstitüsü

KIM, K. (2000); “On Interfirm Power, Channel Climatic, and Solidarity Industrial DistributorSupplier Dyads"; Journal of the Academy of Marketing Science, 28(3), Pg.388-405

KIM, J; PARK, J.Y.; JIN, B., (2008); "Cross-Cultural Examination of the Relationships among Firm Reputation, E-Satisfaction, E-Trust, and E-Loyalty”; International Marketing Review, Vol.25, No.3, Pg.342-337

MORGAN, R.M. and HUNT, S.D.; (1994), “The Commitment-Trust Theory of Relationship Marketing"; Journal of Marketing, Vol.58, (July), Pg.20-38

MOORMAN, C; ZALTMAN, G. and DESPHANDE, R., (1992); "Relationships between Providers and Users of Market Research: The Dynamics of Trust within and Between Organizations"; Journal of Marketing Research, Vol.29, August, Pg.314-28

NOORDEWIER, T.G.; JOHN, G. and NEVIN, J.R.; (1990), "Performance Outcomes of Purchasing Arrangements in Industrial Buyer-Vendor Relationships"; Journal of Marketing, 54, 4, Oct, Pg.80

PINKLEY, R.L. and NORTHCRAFT, G.B.; (1994); “Conflict Frames Of Reference: Implications for Dispute Processes and Outcomes"; Academy of Management Journal, (Feb), 37, 1, Pg.193

ROSENBERG, L.J and STERN, L.; (1971); "Conflict Measurement in the Distribution Channel"; Journal of Marketing Research, 8(Nov), Pg.437-42

SEZEN, B. and YILMAZ, C.; (2007), "Relative Effects of Dependence and Trust on Flexibility, Information Exchange, and Solidarity in Marketing Channels"; Journal of Business and Industrial Marketing, 22/1, Pg.41-51 
STERN, L.W. and REVE, T., (1979); "Interorganizationl Relations in Marketing Channels"; Academy Of Management. The Academy of Management Review, (July), 4, 000003, Pg.405

SCHUL, P.L. and BABAKUS, E.; (1988); “An Examination of the Interfirmpower-Conflict Relationship"; Journal of Retailing, Winter, 64, 4, Pg.381

YILMAZ, C.; KABADAYI, E.T and SEZEN, B., (2002); "Dağitim Kanallarinda Üretici- Bayi Ilişkilerinde Bağimlilik Kavrami Ve Bağimliliğin Işbirliği, Bağlilik Ve Memnuniyet Üzerine Etkileri”; Journal of Dogus University, Vol.5, Pg.181-192

YILMAZ, C. and KABADAYI, E.T (2002); “Dağitim Kanallarinda Bayilerin Üretici Firma Lehine Işbirliği Davranişlarini Etkileyen Faktörleri Inceleyen Bir Araştirma"; Journal of Marmara University Institute of Social Science, Vol.17, Pg.99-106

WILLIAMS, R.J; SCHNAKE, M.E. and FREDENBERGER, W., (2005); "The Impact of Corporate Strategy on a Firms Reputation"; Corporate Reputation Review, 8, 3, Fall, Pg.187

ZEITHAML, Z.A.; (1998); "Consumer Perceptions of Price, Quality and Value: A Means-End Model and Synthesis of Evidence"; Journal of Marketing, Vol 52, No.3, Pg.2-22

KUMAR, N. (2005), “The Power of Power in Supplier Retailer Relationships”; Industrial Marketing Management, 34(Oct), Pg.863-866

LEONIDOU, L.C.; TALİAS, M.A. and LEONIDOU, C.; (2007), "Exercised Power as A Driver of Trust and Commitment in Cross-Border Industrial Buyer-Seller Relationships"; Industrial Marketing Management

LUSCH, R.F.; (1976); “Sources of power: their impact on intra-channel conflict”, Journal of Marketing Research 